УДК 811.111'42:808.51
DOI 10.35433/philology.1(89).2019.87-91
О. І. Назаренко,

старший викладач

(Київський національний університет імені Тараса Шевченка) olganazarenko1@gmail.com ORCID: 0000-0001-628-910

О. С. Нестеренко, асистент

(Київський національний університет імені Тараса Шевченка) oksanaenglishteacher@gmail.com ORCID: 0000-0002-5924-6174

\title{
ОСОБЛИВОСТІ ВЕРБАЛЬНОЇ АКТУАЛІЗАЦІЇ ЕТНІЧНИХ УПЕРЕДЖЕНЬ У ДИСКУРСІ АМЕРИКАНСЬКИХ ПОЛІТИКІВ-РЕСПУБЛІКАНЦІВ
}

Стаття присвячена проблемі аналізу етнічних упереджень як дискурсно-релевантного явища на прикладі політичного дискурсу американських політиків-республіканців. Особлива увага приділяється розгляду окремих складових иьього поняття та наводиться його визначення. Підкреслюється важлива роль етнічних та расових стереотипів як основного джерела етнічних упереджень. Розглядаються характеристики та особливості етнічних упереджень у дискурсі політиків-республіканиів.

Ключові слова: етнічне упередження, етнічний стереотип, гетеростереотип, когнітивна структура, дискурс.

Постановка проблеми. Вивчення проблеми етнічних упереджень набуло великої значимості у руслі досліджень, присвячених аналізу міжетнічних та міжнаціональних відносин. В даний час великий пласт досліджень як теоретичного, так і практичного характерів, фокусується саме на проблемі упереджень, нетерпимості людей до представників інших етнічних груп та національностей. Відчуження та ворожнеча породжуються упередженнями, упередження призводять до знеособленого сприйняття чужої групи або національності як відштовхуючої та негативної, перешкоджають комунікації між представниками різних етносів та пізнанню культур одне одного. Упереджене ставлення позбавляє людей можливостей пізнання особливостей сприйняття світу іншими народами i, відповідно, обмежує можливості пізнання себе та власних особливостей. Зусилля вчених спрямовані на пошук шляхів, які дозволили б знизити міжетнічну напругу та підвищити толерантність до представників інших груп.

У світі, де ускладнення та удосконалення засобів зв'язку призводить до стирання усіх бар'єрів та кордонів, що лежать на шляху до комунікації людей у різних куточках світу, на перший план висувається проблема внутрішніх соціально-психологічних обмежень, які найчастіше виражаються у формі етнічних упереджень. А оскільки упередження актуалізуються лише в мовленні, то вивчення характеру та особливостей такої актуалізації є важливою проблемою.

Саме тому, метою даної статті є аналіз особливостей мовленнєвого вираження етнічних упереджень у політичному дискурсі американських політиків-республіканців.

Аналіз основних досліджень і публікацій. Проблемі дослідження дискурсної реалізації етнічних упереджень присвячена ціла низка робіт таких видатних вчених-мовознавців, як Т. ван Дейк, Р. Водак, М. Рейзігл, Б. Буш, В. Кінтч, Н. Ферклаф, С. Джагер. Наукові розвідки саме цих вчених стали теоретикометодологічною основою для дослідження особливостей вербальної реалізації етнічних упереджень у дискурсі політиків-республіканців.

Виклад основного матеріалу. Міжнаціональні відносини були завжди в центрі уваги держави та громадськості, та особливо важливим дослідження проблем, що стосуються міжнаціональних відносин та етнічної ідентичності, стає в епоху глобалізації. Завдяки глобалізації завершилися складні процеси, які йшли автономно і відокремлено протягом сторіч, i, як результат, було створено новий єдиний простір. Жодна подія, що відбувається на планеті, не залишається непоміченою, і їі наслідки можна спостерігати у різних куточках земної кулі. Вперше в історії людство перебуває в умовах єдиного історичного процесу, при цьому спілкування стає все різноманітнішим та інтенсивним, економіка та політика набувають всесвітнього характеру. За цих умов від рівня дослідження упередженості одних народів проти інших та стереотипних уявлень одного народу про інший залежить подальший історичний, політичний та культурний розвиток людства в цілому.

Однією $з$ найголовніших ідентифікаційних ознак людини є ії етнічна належність, яка усвідомлюється через дихотомію "свій-чужий" [1: 77] Опозиція "свій-чужий" передбачає асиметрію етносоціальних відносин, що призводить до соціальних конфліктів та протирічь. Типові риси представників інших етносів порівнюються із традиціями та цінностями власної нації і, зазвичай, сприймаються як негативні 
та девіантні. Ідеологія етноцентризму, яка базується на засадах, що власна нація є кращою та розвиненішою за інші, є однією із головних причин етнічних (або расових) упереджень.

Поняття "упередження" може означати різні речі залежно від контексту та того чи іншого трактування визначення цього терміну. Т. Нельсон, посилаючись на Г. Гарднера, вважає, що слово "упередження" можна розуміти у буквальному сенсі як апріорно прийняте судження про що-небудь [2: 23]. Таким чином, упередження може включати або мати на увазі оціночне (позитивне або негативне) ставлення до об'єкта. Аналізуючи різні трактовки поняття "упередження", Т. Нельсон звертає увагу на те, що у багатьох випадках використовується термін "оцінка", яку він розглядає як установку [2: 23]. Установку визначають як загальну оцінку відповідного об'єкту, як характеристику, що виміряється за віссю "добре-погане" або "сприятливе - несприятливе". Таким чином, установку розглядають як таку, що складається 3 трьох компонентів: поведінкового, афективного та когнітивного [2: 22]. Поведінковий аспект виражає потенційну готовність особистості реалізувати певну модель поведінки стосовно об'єкту упереджень, афективний - демонструє емоційно-оціночне ставлення до нього, когнітивний аспект включає знання, поняття та уявлення про цей об'єкт. Етнічне упередження розглядається як негативне ставлення до представників інших націй, свідоме засудження та несприйняття людини виключно 3 причини її належності до якоїсь іншої етнічної групи. Людині, що знаходиться під впливом етнічного упередження, не подобаються ті, хто належать до інших націй та національностей, та є не схожими на неї і характеризуються певними, неприйнятними для даної людини, ознаками [3: 437].

Класик теорії упереджень, який один із перших зайнявся фундаментальною розробкою даної проблеми, Г. Олпорт дає визначення упередженню, спираючись на його афективну складову як базову: "упередження - це антипатія (різке негативне почуття, засноване на помилковій та жорсткій генералізаціі). Його можна відчувати та виражати. Воно може бути спрямоване проти групи в цілому та проти окремого індивіда, оскільки він являється членом цієї групи [4: 13].

Провідні лінгвісти сучасності розглядають етнічні упередження як сформовані певним чином когнітивні конструкти, підкреслюючи той факт, що саме когнітивний компонент є основоположним для їхнього аналізу [4-6]. Ми поділяємо точку зору Т. ван Дейка, який є провідним фахівцем у дослідженні цього феномену у лінгвістиці, що "етнічні упередження є як соціальним, так і когнітивним явищем. Вони $\epsilon$ не просто характеристикою індивідуальних переконань та почуттів певної особи стосовно якоїсь етнічної групи, а спільною формою соціальної репрезентації членів певної групи, набуті протягом процесу соціалізації і трансформовані та відтворені у соціальній комунікації та взаємодії" [4: 13]. Вивчаючи способи та механізми репрезентації етносоціальної дійсності науковець наголошує, що вираження, передача та формування етносоціальних установок здійснюється за допомогою дискурсної взаємодії, що саме дискурс стає основним алгоритмом засвоєння та передачі етносоціального досвіду. Т. ван Дейк також підкреслює, що когнітивні установки не є статичними, а підлягають змінам завдяки динамічному характеру реальних мовленнєвих ситуацій [5: 21].

Етнічні упередження є когнітивно складними формами, оскільки окрім онтологічної складової, вони містять аксіологічні, оціночні значення.

Утворення етнічних упереджень тісно пов'язане із етнічними стереотипами, які є основним джерелом формування упереджень.

Етнічний стереотип - це образний, спрощений, схематизований, емоційно-насичений, цілісний та надзвичайно стійкий образ якої-небудь етнічної групи або спільноти, що поширюється на усіх іiі представників і $є$ орієнтованим в минуле. Одними із найважливіших ознак етностереотипів $€$ їхня суб'єктивність, ілюзорність та перевантаженість "помилковим компонентом". В етнічних стереотипах значною мірою фіксуються психічні особливості етносу, який піддається стереотипізації, особливості його життя, поведінки, його моральні, фізичні, розумові та інші якості [7: 139-141]. Етностереотипи розглядають як уявлення, сформовані в етнічній самосвідомості, що схематично та виразно передають образ того чи іншого явища та визначають його місце в ієрархії цінностей, що притаманна тій чи іншій етнічній групі. Етностереотипний образ включає в себе лише найяскравіші, екзотичні та незвичні риси, які вдалося виділити при знайомстві та спілкуванні з певною етнічною групою. Це породжує спрощені схеми, які допомагають особистості орієнтуватись в соціальному просторі, ідентифікувати себе 3 етнічною спільнотою та встановити певні взаємовідносини з іншою етнічною групою.

Етнічні стереотипи поділяються на автостереотипи, які є сукупністю характеристик про дійсні або уявні риси, що притаманні власній етнічній групі, та є "культурно-схвальними" та представляють, як правило, комплекс позитивних оцінок. Автостереотипи можуть стати джерелом етноцентризму.

Гетеростереотипи - це образи представників інших етнічних груп, що склалися у даної групи, які часто є негативними та емоційно-оцінними.

Гетеро- та автостереотипи є тісно пов'язаними, оскільки етнічна ідентифікація та відмінність реалізуються через порівняння та протиставлення "ми (свої) - вони (чужі) [8: 30].

Отже, ми вбачаємо етнічні упередження як гетеростереотипізовані, емоційно-оцінні, когнітивні структури, що реалізуються у дискурсі за допомогою мовних форм. 
Маємо зазначити, що етнічні упередження $є$ достатньо типовими для промов та висловлень американських політиків-республіканців. Свої оціночні та гетеростереотипізовані уявлення та переконання про представників інших націй та етнічних груп (особливо емігрантів) вони передають за допомогою оціночних номінативних одиниць, які характеризують вкрай негативні риси характеру. "Black guys counting my money! I hate it. ... I think that the guy is lazy. And it's probably not his fault, because laziness is a trait in blacks. It really is, I believe that. It's not anything they can control."[9]. Дональд Трамп неодноразово стверджував, що Барак Обама, будучи президентом, не працював ретельно та наполегливо та вів дозвільний спосіб життя. "Obama has admitted that he spends mornings watching @ESPN. Then he plays golf, fundraises \& grants amnesty to illegals" [9]. Трамп використовує дієслівні одиниці із семантикою дозвілля та відпочинку, щоб охарактеризувати першого та поки єдиного темношкірого президента США як безвідповідальну та ледачу людину.

Говорячи про іммігрантів із Африки та країн Латинської Америки та темношкірих громадян Сполучених Штатів, Дональд Трамп характеризує їх як злодіїв, злочинців та представників кримінального світу, які загрожують безпеці та добробуту порядних та законослухняних американських громадян та вживає номінативні одиниці із негативною та кримінальною семантикою."When Mexica is sending its people, they are not sending their best. They are sending people with a lot of problems. They are bringing drugs, they are bringing crime. They are criminals and rapists. They are not the right people." [10].Трамп підкреслює особливу небезпеку злочинів, скоєних темношкірими радикальними ісламістами у Великій Британії, імпліцитно порівнюючи цю ситуацію із ситуацією у Сполучених Штатах, хоча в подальшому ці дані не підтвердились. "Just out report: "United Kingdom crime rises $13 \%$ annually amid spread of Radical Islamic terror." Not good, we must keep America safe!" Навіть характеризуючи свого попередника Барака Обаму, Трамп наголошує на його злочинності та непорядності. " An 'extremely credible source' has called my office and told me that @,BarackObama's birth certificate is a fraud." [9]. Наголошуючи на тому, що Обама має підробне свідоцтво про народження, Трамп переконує американців, що Обама не мав юридичного права бути президентом США. Як результат, в американських ЗМІ навіть з'явився такий акронім, як "birtherism", що походить від слів "birthers" (прихильники теорії, згідно якої Барак Обама народився за межами Сполучених Штатів і не мав права займати посаду президента) та слова "racism" (расизм) [11].

Підкреслюючи небезпеку імміграції та другорядність власних темношкірих та латиноамериканських громадян, Трамп наголошує на їхній бідності, жалюгідності, та на тому факті, що вони $є$ носіями небезпечних хвороб, вживаючи при цьому дерогативні мовні одиниці із принизливим значенням. "15,000 recent immigrants from Haiiti all have AIDS and that 40,000 Nigerians, once seeing the United States, would never "go back to their huts" in Africa." [9]. "You're living in poverty, your schools are no good, you have no jobs, 58 percent of your youth is unemployed. What the hell do you have to lose?" [11].

Упередженість до темношкірих та латиноамериканських іммігрантів виражається також у структурі дискурсу політиків-республіканців та формується аксіологічними пропозиціями: темношкірі/латиноамериканці - погані, білі - хороші. "Why we having all these people from shithole countries come here? We should instead bring more people from countries such as Norway, whose Prime Minister I met with on Wednesday." [12]. (Таку принизливу та зневажливу номінативну одиницю президент використовує для характеристики етнічних представників таких країн, як Гаїті та Ель Сальвадор).

Представники республіканської партії Каліфорнійського університету у своїй новій платформі зазаначають, що університетські етнічні спільноти є центрами спотвореної поведінки та діють всупереч традиційним вірованням американських громадян. "Ethnic, women's, and sexually deviant 'community centers' and 'theme dormitories' encourage degenerate behavior and go against everything we believe as conservatives, and we flatly refuse to fund them." Автори платформи вдаються до лексичних одиниць 3 дерогативною конотацією, щоб ще раз підкреслити меншовартість представників етнічних меншин та відмовити їм у фінансуванні.

Упереджене ставлення до етнічних спільнот, представники яких іммігрують до Сполучених Штатів, часто також виражається за допомогою синтаксичних структур порівняння: "We're taking people out of the country. You wouldn't believe how bad these people are. These aren't people. These are like animals. And we're taking them out of the country at a level and at a rate that's never happened before." [13].

Дональд Трамп звинувачує суддю федерального суду Гонзало Курієла у нечесності та упередженості тільки через його мексиканське походження, тим самим висловлюючи недовіру федеральному суду США як структурі. "Let me just tell you, I've had horrible rulings, I've been treated very unfairly by this judge. Now, this judge is of Mexican heritage. I'm building a wall, OK? I'm building a wall. I am going to do very well with the Hispanics, the Mexicans." [14].

Рой Стюарт Мур, американський політик та юрист, республіканський кандидат в Сенат США в 2017 році, принизив чорношкірого журналіста, зазначивши, що Америка була великою державою востаннє за часи рабства, застосувавши для цієї мети синтаксичну конструкцію співвідношення. "I think America was 
great at the time when families were united-even though we had slavery. They cared for one another. Our families were strong, our country had a direction." [15].

Висновки та перспективи подальшого дослідження. Отже, етнічні упередження $\epsilon$ типовою характеристикою дискурсу американських політиків-республіканців, базуються на етнічних та расових стереотипах та актуалізуються за допомогою певних мовленнєвих структур. Перспектива подальших досліджень проблеми полягає у вивченні та аналізі різноманітних способів та особливостей реалізації етнічних та расових упереджень у різних формах дискурсу.

\section{СПИСОК ВИКОРИСТАНИХ ДЖЕРЕЛ ТА ЛІТЕРАТУРИ}

1. Lippman W. Public Opinion / W. Lippman. - New York : Harcout Brace and Co., 1922. - 427 p.

2. Нельсон Т. Психология предубеждений. Секреты шаблонов мышления, восприятия и поведения / Т. Нельсон. - Санкт-Петербург : Прайм Еврознак, 2003. - 384 с.

3. Майерс Д. Социальная психология / Д. Майерс. - Санкт-Петербург : Питер, 2011. - 800 c.

4. Dijk T. A. van. Prejudice in Discourse : An Analysis of Ethnic Prejudice in Cognition and Conversation / T. A. Van Dijk. - Amsterdam : John Benjamins Publishing Company, 1984. - 294 p.

5. Dijk T. A. van. Communicating Racism. Ethnic Prejudice in Thought and Talk / T. A. van Dijk. - London : Sage Publications, 1987. - 437 p.

6. Resigl M. Discourse and Discrimination. Rhetorics of Racism and Antisemitism / M. Resigl, R. Wodak. - London. - New York : Routledge, 2001. - 298 p.

7. Стефаненко Т .Г. Этнопсихология / Т. Г. Стефаненко. - Москва : Аспект Пресс, 2008. - 368 с.

8. Гасанов И .Б. Национальные стереотипы и образ врага / И. Б. Гасанов. - Москва : Прогресс, 1994. -39 с.

\section{ДЖЕРЕЛА ІЛЮСТРАТИВНОГО МАТЕРІАЛУ}

1. https://www.nytimes.com/interactive/2018/01/15/opinion/leonhardt-trump-racist.html

2. https://www.youtube.com/watch? $\mathrm{v}=$ apjNfkysjbM\&t=249s

3. https://www.vox.com/2016/7/25/12270880/donald-trump-racism-history

4. https://www.washingtonpost.com/politics/trump-attacks-protections-for-immigrants-from-shithole-countries-inoval-office

5. https://www.bbc.com/news/av/world-us-canada-44148697/trump-immigrant-gangs-animals-not-people

6. https://edition.cnn.com/2018/02/27/politics/judge-curiel-trump-border-wall/index.html

7. http://time.com/5056590/roy-moore-america-great-slavery

\section{REFERENCES (TRANSLATED \& TRANSLITERATED)}

1. Lippman W. Public Opinion / W. Lippman. - New York : Harcout Brace and Co., 1922. - 427 p.

2. Nelson T. Psikhologiia predubezhdenii. Sekrety shablonov myshleniia, vospriiatia i povedeniia [The Psychology of Prejudice.The Secrets of Stereotypes of Thinking, Perception and Behavior] / T. Nelson. - Sankt-Peterburg: Praim Evroznak, 2003. - $384 \mathrm{~s}$.

3. Maiers D. Sotsial'naia psikhologiia [Social Psychology] / D. Maiers. - Sankt-Peterburg : Piter, 2011. $-800 \mathrm{~s}$.

4. Dijk T. A. van. Prejudice in Discourse : An Analysis of Ethnic Prejudice in Cognition and Conversation / T. A. Van Dijk. - Amsterdam : John Benjamins Publishing Company, 1984. - 294 p.

5. Dijk T. A. van. Communicating Racism. Ethnic Prejudice in Thought and Talk / T. A. van Dijk. - London : Sage Publications, 1987. $-437 \mathrm{p}$.

6. Resigl M. Discourse and Discrimination. Rhetorics of Racism and Antisemitism / M. Resigl, R. Wodak. - London. - New York : Routledge, 2001. - 298 p.

7. Stefanenko T. G. Etnopsihologiia [Ethnopsychology] / T. G. Stefanenko. - Moskva : Aspekt Press, 2008. - 368 s.

8. Gasanov I. B. Natsionalnyie stereotypy i obraz vraga [National Stereotypes and the Image of Enemy] / I. B. Gasanov. - Moskva : Progress, 1994. - 39 s.

\section{SOURCES OF ILLUSTRATIVE MATERIALS}

1. https://www.nytimes.com/interactive/2018/01/15/opinion/leonhardt-trump-racist.html

2. https://www.youtube.com/watch? $\mathrm{v}=$ apjNfkysjbM\&t=249s

3. https://www.vox.com/2016/7/25/12270880/donald-trump-racism-history

4. https://www.washingtonpost.com/politics/trump-attacks-protections-for-immigrants-from-shithole-countries-inoval-office

5. https:/www.bbc.com/news/av/world-us-canada-44148697/trump-immigrant-gangs-animals-not-people

6. https://edition.cnn.com/2018/02/27/politics/judge-curiel-trump-border-wall/index.html

7. http://time.com/5056590/roy-moore-america-great-slavery.

\section{Назаренко О. И., Нестеренко О. Е. Особенности вербальной актуализации этнических предубеждений в дискурсе американских политиков республиканцев.}

Статья посвящена проблеме анализа этнических предубеждений как дискурсно-релавантного явления на примере политического дискурса американских политиков-республиканцев. Особое внимание уделяется рассмотрению отдельных составляющих этого понятия и приводится его определение. 
Подчеркивается важная роль этнических и расовых стереотипов как основного источника этнических предубеждений. Рассматриваются характеристики и особенности этнических предубеждений в дискурсе политиков-республиканцев.

Ключевые слова: этническое предубеждение, этнический стереотип, гетеростереотип, когнитивная структура, дискурс.

\section{Nazarenko O. I., Nesterenko O. Ye. The Pecualiarities of Verbal Actualization of Ethnic Prejudices in the Discourse of the American Politicians of the Republican Party.}

The article is devoted to the problem of the analysis of ethnic prejudices as discourse relevant phenomenon by means of an example of the political discourse of the American politicians of the Republican party. The notion "prejudice" is regarded as an element consisting of three basic components: behavioural, emotive and cognitive. The article underlines the fact that modern linguists regard ethnic prejudices as cognitive structures and pay special attention to their cognitive component as the main one. Ethnic and racial stereotypes are considered to be the main source of ethnic prejudices and divided into two groups: autostereotypes and heterostereotypes. Autostereotypes are usually positive and laudable ideas about our own ethnic group whereas heterostereotypes present negative images of other ethnic groups. Ethnic prejudices are viewed as heterostereotyped, emotional and appraisive cognitive structures which are actualized in discourse with the help of certain verbal and syntactic structures. Special attention is paid to the ways and forms of expressing ethnic prejudices by the American politicians of the Republican party. Negative nominative units, derogatory structures, comparative syntactic constructions, verbal elements which express distrust and suspicion are analyzed as the commonest ways of airing ethnic prejudices by the American politicians of the Republican party.

Key words: ethnic prejudice, ethnic stereotype, heterostereotype, cognitive structure, discourse. 